\title{
Proximate composition, mineral content and functional properties of Tarap (Artocarpus odoratissimus) seed flour
}

\author{
Noorfarahzilah, M., Mansoor, A. H. and *Hasmadi, M.. \\ Food Technology and Bioprocessing Program, Faculty of Food Science and Nutrition, \\ Universiti Malaysia Sabah, 88400 Kota Kinabalu, Sabah, Malaysia
}

\begin{abstract}
Article history:
Received : 25 April 2017

Received in revised form : 9 June 2017

Accepted :10 June 2017

Available Online :

15 June 2017
\end{abstract}

\section{Keywords:}

Artocarpus odoratissimus Functional properties

Proximate analysis

Seeds flour

\section{DOI:}

http://doi.org/10.26656/ fr.2017.3.025

\begin{abstract}
Tarap seed (Artocarpus odoratissimus) is one of the popular snacks among Borneo Island people especially in Sabah, Malaysia. Their flesh and seed are such a potential food source but they are not fully exploited. Therefore, this study was conducted to determine its nutritional composition, mineral content and functional properties of Tarap seed flour (TSF). The proximate analysis (protein, carbohydrate, fat, crude fiber, ash, moisture), minerals content and functional properties (powder particle size, bulk density, oil and water absorption capacity, emulsion capacity, foaming ability, least gelling concentration, swelling ability and pasting properties) were determined. The proximate analysis results obtained showed that TSF had $49.65 \%$ carbohydrate, $15.60 \%$ crude fat, $12.3 \%$ crude fibers, $8.8 \%$ crude protein, $1.17 \%$ ash and $12.5 \%$ moisture. Most abundant mineral found in Tarap flour was potassium, followed by magnesium, calcium, and natrium. The results showed that TSF has an average particle size of $166.02 \mu \mathrm{m}$ with low bulk density $\left(0.57 \mathrm{~g} / \mathrm{cm}^{3}\right)$ as compared to wheat flour. Water and oil absorption capacities of TSF were 2.61 and $1.69 \mathrm{~g} / \mathrm{g}$, respectively, while the efficiency of emulsification was $14.8 \%$. Least gelation concentration was found to be $12 \%$ while foaming ability was $7 \%$. Swelling ability results showed a steady increment from $60^{\circ} \mathrm{C}$ to $70^{\circ} \mathrm{C}$ but sharp increased observed from $70^{\circ} \mathrm{C}$ to $80^{\circ} \mathrm{C}$. From the results presented, it can be concluded that TSF has a great potential for use in the formulation of composite flours to be used as ingredients in the food industry.
\end{abstract}

\section{Introduction}

Tarap is one of the most delicious tropical fruit and can be found extensively in Borneo, particularly in Sabah, Sarawak, and Brunei. Botanically it is known as Artocarpus odoratissimus and belongs to the Moraceae plant family. Based on morphology perspective, the fruit can be regarded as an intermediate shape between the jackfruit and breadfruit (Galang, 1955; Subhadrabandhu, 2001). The tree of the Tarap grows to a height of $20-25 \mathrm{~m}$ and is usually grown from seed, fruiting starts when the tree is about 4-5 years old. The flowers, both male and female look like light-bulb-shaped and sized fruits, the male inflorescence drop to the ground soon after releasing pollen while the female heads continue to grow to a large roundish and almost football sized fruit covered with spiny protuberances. The fruit is edible, oblong, about 12 inches $(20 \mathrm{~cm})$ long, and can weigh a few pounds. Its skin is covered with soft spines and has an appearance which is close to that of the durian or the jackfruit. The snowy white fruit flesh-covered seeds are attached to a centre core inside the fruit and can be seen (and eaten) when the skin is removed. The flesh is sweet, fruity and has a strong smell like durian and generally eaten fresh. Its seeds can also be eaten when roasted. It is reported that young fruits are sometimes eaten as vegetables (Tang et al., 2013).

Tarap is a seasonal fruit which is very popular among the people in the Borneo Island. Tarap grows wild in subtropical regions, also known by various names in the area such as Tarap (Malaysia), Marang (Sulu), and Khanun Sampalor (Thailand) (Subhadaraandhu, 2001). Usually, the fruits are eaten fresh and have a strong aroma like durian, while the content of the fruit is white and juicy and the fruit skin is covered with soft expanded spines, yellowish green and easily resolved. When it matured, the fruit should be plucked from the branches of the tree itself after reached the maturity to avoid fruit damage.

Among communities in Sabah, Tarap seeds from the matured fruit usually collected, cleaned with water and drained before fried until golden brown. Tarap seed is slightly fatty taste like hazelnuts that are delicious eaten as snacks. In Indonesia, Tarap 
seeds were fried and added a bit of flavor and then marketed the snacks (Ithnin, 2008). There are previous studies that produced flour from seeds such as breadfruit seed flour, jackfruit seed flour, lupin seed flour, pumpkin seed flour and passion fruit seed flour (Sathe et al., 1982; Fagbemi and Oshiodi, 1991; Adepeju et al., 2011; Chowdhury et al., 2012; Akubor et al., 2013). While Tarap fruit seed was served in a variety of dishes, especially by the locals in Sabah but there have no studies had been explored on Tarap seed. Thus, the aim of this study was to determine the proximate composition and to identify functional properties of TSF. This is very important in determining the reliability of the flour before it is developed into a food product in the future.

\section{Materials and methods}

The fruits of A. odoratissimus were collected from Kota Marudu and Sipiting, Sabah, Malaysia in September to November 2015. Fruits were selected for uniformity of size and freedom of visual defects. Matured and ripen Tarap fruit was selected based on yellowish green color, strong aroma and the average diameter of $15-20 \mathrm{~cm}$. Tarap fruit was peeled and the pulp separated from seeds. Tarap seeds were cleaned with water to remove the pulp and then drained. Tarap seeds were dried at a temperature of $40^{\circ} \mathrm{C}$ for 2-3 days in the oven cabinet. Once dried, the Tarap seeds were ground using a blender and sieved using a sieve size $<250 \mu \mathrm{m}$. Then the Tarap seed flour (TSF) was stored in an airtight container and labeled for further analysis.

\subsection{Proximate and mineral analysis}

The analysis was carried out using AOAC method (2000) to determine moisture, crude protein, crude fat, crude fiber and ash of all the all samples. The moisture content was measured by oven drying at $105^{\circ} \mathrm{C}$ to constant weight. The crude protein content was determined by using Kjeldhal's method (Kjeltex System-Texator) where the nitrogen value was converted to protein by multiplying a factor of 6.25 . The crude fat was evaluated by using Soxhlet system (Soxtec System-Texator) while carbohydrate content was determined by difference method. Ash content was determined by dry-ashing in a furnace at $550^{\circ} \mathrm{C}$ for $24 \mathrm{~h}$. For mineral quantification, the samples were digested in $5 \mathrm{ml}$ of $\mathrm{HNO}_{3} / \mathrm{HClO}_{4}$. The elements $\mathrm{Ca}$, $\mathrm{K}, \mathrm{Na}, \mathrm{Mg}$, and $\mathrm{Zn}$ were measured by using atomic absorption spectrophotometry (AAS) using a Varian Spectra atomic absorption spectrophotometer, model A-400.

\subsection{Particle size distribution}

The particle size distributions of the TSF was measured by dry sieving using a series of (ASTM test sieves, Retsch, Germany) of nominal opening sizes between $63-250 \mu \mathrm{m}$. The sieve series selected were based on the range of particles in the sample. A total of $100.00 \pm 0.50 \mathrm{~g}$ of powders was placed on the top of the sieve and then sieved for 30mins with a mechanical sieve shaker (Retsch, type RV, Germany). Each collected fraction was weighed and recorded.

\subsection{Bulk density}

Bulk density of the flours was determined according to the method of Okaka and Potter (1977) using the gravimetric method. The sample $(100.00 \pm 0.05 \mathrm{~g})$ was weighed and gently filled in $250 \mathrm{ml}$ graduated cylinder. The bottom of the cylinder was gently tapped 10 times until there was no further diminution of the sample level. Bulk density was expressed as weight of sample per unit volume of sample $(\mathrm{g} / \mathrm{ml})$. Measurements were made in triplicate.

\subsection{Water absorption capacity}

Water absorption capacity was determined using the method described by AACC method (2000). Distilled water $(40 \mathrm{~mL})$ was added to $2.00 \pm 0.05 \mathrm{~g}$ of Tarap flour in a pre-weighed centrifuge tube. The dispersions were stirred occasionally, held for 30min, followed by centrifugation for $15 \mathrm{~min}$ at $1000 \times \mathrm{g}$. The supernatant was decanted, excess moisture was removed by draining for 24 hours at $50^{\circ} \mathrm{C}$, and the sample was reweighed. The amount of water bound by the flour was determined by difference and expressed as weight of water bound by dry flour $(100 \mathrm{~g})$. The water absorption capacity was calculated as follows:

(Volume before centrifuge - Volume after centrifuge) / Volume of sample

\subsection{Oil absorption capacity}

The oil absorption capacity was measured using the method reported by Yu et al. (2007) was used with modifications. Samples $(1.00 \pm 0.05 \mathrm{~g})$ were mixed with $10 \mathrm{ml}$ of vegetable oil in preweighed centrifuge tubes. The contents were stirred for 1 min with a thin brass wire to disperse the sample in the oil. After a holding period of $30 \mathrm{~min}$, the tubes were centrifuged for $20 \mathrm{~min}$ at $3000 \times \mathrm{g}$ at room temperature $\left(25^{\circ} \mathrm{C}\right)$. The separated oil was then removed with a pipette and the tubes were inverted to drain the oil prior 
to reweighing. The oil absorption capacity was expressed as grams of oil bound per gram of the sample on a dry basis. The oil absorption capacity was calculated as follows:

(Volume before centrifuge - Volume after centrifuge) / Volume of sample

\subsection{Emulsification ability}

The method by Yu et al. (2007) was used to determine the ability of the sample to be emulsified. Two grams of sample was mixed with $200 \mathrm{ml}$ of distilled water and blended for 2 minutes using a grinder at maximum speed. Then $200 \mathrm{ml}$ of vegetable oil is added to the mixture little by little under the continuous blending conditions. Blending was stopped every 2 min to check for emulsion breakage. When a clear emulsion breakage was observed, the total volume of oil added to was recorded and used to calculate emulsification ability as volume $(\mathrm{ml})$ of oil emulsified per gram of flour.

\subsection{Foaming ability}

Foaming ability (FA) measurement was performed according to Sridaran et al. (2012). A total of $250 \pm 1$ $\mathrm{mg}$ of Tarap flour was mixed with $250 \mathrm{ml}$ of distilled water and the volume (volume before whipping) was measured by using a measuring cylinder. Then, the solution was whipped by using kitchen blender and the volume (volume after whipping) was measured again. The samples were then allowed to stand for 60 min at room temperature $\left(25 \pm 1^{\circ} \mathrm{C}\right)$ and the volume (volume after standing) was measured. The foaming ability was calculated as follows:

FA $(\%)=[($ Volume after whipping - Volume before whipping) $\times 100] /$ Volume before whipping

\subsection{Least gelation concentration}

Least gelation concentration was determined by the method of Sathe and Salunkhe (1981). Sample suspensions of $2,4,6,8,10,12,14,16,18$ and $20 \%$ $(\mathrm{w} / \mathrm{v})$ were prepared from distilled water in test tubes. Five milliliter of each of the prepared dispersions was transferred into a test tube. The dispersions were heated in a boiling water bath for 1 hour at $80 \pm 1^{\circ} \mathrm{C}$ followed by rapid cooling in a cold water-bath. The samples were further cooled at $4 \pm 1^{\circ} \mathrm{C}$ for 2 hours. The least gelation was determined as the concentration when the sample from the inverted test tube did not slip or fall.

\subsection{Swelling capability}

Swelling behaviors were determined by the method of Li and Yeh (2001). Five gram of the sample was weighed and transferred into a clean dry test tube and then weighed $\left(\mathrm{W}_{1}\right)$. The mix was then dispersed in $30 \mathrm{ml}$ of distilled water using a magnetic stirrer. The resultant slurry was heated at desired temperatures of $40^{\circ} \mathrm{C}, 50^{\circ} \mathrm{C}, 70^{\circ} \mathrm{C}, 80^{\circ} \mathrm{C}$ and $90^{\circ} \mathrm{C}$ for $30 \mathrm{~min}$ in a water bath, cooled to room temperature, and centrifuged at $3000 \mathrm{rpm}$ for $10 \mathrm{~min}$. The supernatant liquid was decanted and the centrifuge tube was placed in a hot air oven and dried for $30 \mathrm{~min}$ at $50^{\circ} \mathrm{C}$. The residue was weighed $\left(\mathrm{W}_{2}\right)$. Swelling index for each temperature was calculated as the difference between $\mathrm{W}_{2}-\mathrm{W}_{1}$ divided by weight of flour. Swelling capability was calculated as follows:

$$
\left[\mathrm{W}_{2}(\mathrm{~g})-\mathrm{W}_{1}(\mathrm{~g})\right] / \text { weight of sample }(\mathrm{g})
$$

\subsection{Pasting properties}

Pasting properties of TSF was measured according to the method described by Hasmadi et al. (2010) using the Rapid Visco Analyzer (Newport Scientific, Australia) instrument. The RVA measurements were performed using $4.00 \mathrm{~g}$ of sample and $24.00 \mathrm{~g}$ of distilled water, followed by mixing in the canister and placing in the RVA. The suspension was kept at $25^{\circ} \mathrm{C}$ for $2 \mathrm{~min}$, heated to $95^{\circ} \mathrm{C}$ for 6 min at $13.5^{\circ} \mathrm{C} /$ $\mathrm{min}$, and kept at $95^{\circ} \mathrm{C}$ for $3 \mathrm{~min}$; it was then cooled to $25^{\circ} \mathrm{C}$ at $14^{\circ} \mathrm{C} / \mathrm{min}$ for $6 \mathrm{~min}$ and kept at $25^{\circ} \mathrm{C}$ for 2 $\mathrm{min}$. The peak viscosity and the final viscosity were determined from the RVA plots. Three repetition measurements were conducted to obtain the reported value.

\section{Results and discussion}

\subsection{Proximate and mineral composition}

Proximate and mineral analysis results are summarized in Table 1. The proximate and mineral composition shows that the seeds have high protein, fat and magnesium content. Proximate analysis results found that TSF consist of $12.50 \%$ moisture, $8.78 \%$ protein, $15.60 \%$ fat, $12.30 \%$ crude fiber $1.17 \%$ ash, and $49.65 \%$ carbohydrate. The results show that the seeds could provide a significant amount of fiber, protein, and fat in our diet. The protein content measured somehow higher than previously reported by Tang et al. (2013). The amount of protein obtained also lower compared to other seeds flour such as jackfruit (9.51-11.83\%), breadfruit kernel (17\%) and 
pumpkin seed flour (25.4\%) (Akubor et al., 2000; Mukprasirt and Sajjaanantakul, 2004; Ardabili et al., 2011). The stage of maturity and the growing environment are amongst the factors that affect the protein content. The fat content in the seed is higher than breadfruit $(9.0 \%)$, mango kernel $(9.4 \%)$ and jackfruit seed flour $(1.94-2.19 \%)$ as reported by Akubor et al. (2000), Arogba (1999), and Mukprasirt and Sajjaanantakul(2004). The fat content is important in human diets as it aids in the absorption of soluble vitamins. Carbohydrate content was lower than found in breadfruit (58.9\%) and jackfruit seed flour (66.86 $-70.22 \%$ ) (Akubor et al., 2000; Chowdhury et al., 2012). However, the values obtained were higher than pumpkin seeds (25.4\%) and almond (31.3 - 37.8\%) (Ardabili et al., 2011; Mbah et al., 2013). This may be due to the geographic and climatic differences of places where the seeds are grown. Table 1 shows the minerals content in TSF. Potassium is the major element recorded. Meanwhile, magnesium is the second most abundant mineral present followed by calcium. The results obtained are in agreement with the values reported by Tang et al. (2013) where they reported potassium was the highest mineral, followed by magnesium and calcium.

Table 1. Proximate and mineral composition of TSF

\begin{tabular}{ll}
\hline Composition & Weight mass \\
\hline Moisture, (\%) & $12.50 \pm 0.38$ \\
Ash, (\%) & $1.17 \pm 0.16$ \\
Crude fibre, (\%) & $12.30 \pm 0.11$ \\
Protein, (\%) & $8.78 \pm 0.04$ \\
Fat, (\%) & $15.60 \pm 1.22$ \\
Carbohydrate, (\%) & $49.65 \pm 0.00$ \\
Calcium, $(\mathrm{mg} / 100 \mathrm{~g})$ & $36.46 \pm 0.02$ \\
Potassium, $(\mathrm{mg} / 100 \mathrm{~g})$ & $259.82 \pm 0.02$ \\
Zinc, $(\mathrm{mg} / 100 \mathrm{~g})$ & $2.92 \pm 0.04$ \\
Magnesium, $(\mathrm{mg} / 100 \mathrm{~g})$ & $415.71 \pm 0.03$ \\
Sodium, $(\mathrm{mg} / 100 \mathrm{~g})$ & $10.23 \pm 0.02$ \\
\hline Results are $\mathrm{means} \pm$ standard error $(\mathrm{n}=3)$ &
\end{tabular}

\subsection{Particles size distribution and bulk density}

Besides flour protein content, flour quality is also determined by flour particle size distribution. It is reported that higher amount of smaller flour particles leads to a less extensible and less fluidable dough. Furthermore, narrow flour particle size distribution is associated with higher water absorption capacity and enzymatic susceptibility (Rukshan, 2001). Particle size distributions for TSF are shown in Table 2. The results revealed that over $79 \%$ of the particles were smaller than $0.15 \mathrm{~mm}$ while only $21 \%$ greater than
$0.15 \mathrm{~mm}$. Particle size has been considered as one of the most important physical properties which affect the flowability of powders. It was shown that smaller particles sizes have higher cohesiveness properties due to the higher degree of contact area and stronger intermolecular force between particles (Landillon et al., 2007).

Table 2. Physical dimensions of TSF

\begin{tabular}{lc}
\hline \multicolumn{1}{c}{ Parameter } & Value \\
\hline Particle sizes average,$(\mu \mathrm{m})$ & $166.02 \pm 0.21$ \\
$\leq 250(\%)$ & $20.8 \pm 0.44$ \\
$\leq 150(\%)$ & $73.7 \pm 0.24$ \\
$\leq 63(\%)$ & $5.5 \pm 0.08$ \\
Bulk density, $\left(\mathrm{g} / \mathrm{cm}^{3}\right)$ & $0.57 \pm 0.04$ \\
\hline
\end{tabular}

Results are means \pm standard error $(n=3)$

The flour exhibited fairly low in bulk densities $\left(0.57 \mathrm{~g} / \mathrm{cm}^{3}\right)$ which suitable for the bakery products as reported by Akubor and Ukwuru (2003). Bulk density is a measure of heaviness of a flour sample. Bulk density which is an indication of the porosity of flours influences package design, material handling and application in wet processing of foods (Sharma et al., 2012). Bulk density is a measure of heaviness of a flour sample. The low bulk density of the flours implied that their packaging materials will be less dense which is economic in terms of packaging cost.

\subsection{Functional properties}

Table 3. Functional properties of TSF

\begin{tabular}{lc}
\hline \multicolumn{1}{c}{ Functional Parameters } & Value \\
\hline Water absorption capacity, (g/g) & $2.61 \pm 0.01$ \\
Oil absorption capacity, (g/g) & $1.39 \pm 0.02$ \\
Emulsified ability, (\%) & $14.80 \pm 0.16$ \\
Foaming ability, (\%) & $7.00 \pm 0.05$ \\
Least gelling concentration, (\%) & $12.00 \pm 0.00$ \\
Colour measurement, & \\
- L*(Lightness) & $74.59 \pm 0.12$ \\
- a*(+ve=red, -ve=green) & $8.13 \pm 0.19$ \\
- b*(+ve=yellow, -ve= blue) & $6.23 \pm 0.24$ \\
- Whitness index & $72.60 \pm 0.00$ \\
\hline
\end{tabular}

Results are means \pm standard error $(n=3)$

Table 3 shows functional properties of TSF. The water absorption capacity recorded for TSF was $2.61 \mathrm{~g} / \mathrm{g}$. The value obtained is higher than values reported for wheat flour $(0.75 \mathrm{~g} / \mathrm{g}$ ) (Akubor et al., 2013), breadfruit flour $(1.55 \mathrm{~g} / \mathrm{g})$ (Adepeju et al., 2011) and jackfruit seed flour $(2.03 \mathrm{~g} / \mathrm{g}$ ) (Chowdhury et al., 2012). Major chemical compositions; protein and carbohydrates are responsible for the increase 
of the water absorption capacity of flour, as both components are part of the polar hydrophilic (Eltayeb et al., 2011). Besides that, smaller particle size was also associated with higher water intake. In addition, the amount of water absorption capacity is also used as a parameter for the amount of water used during gelatinization (Elkhalifa and Bernhardt, 2010) and the existence of a few amino acids in flour (Butt and Batool, 2010). Water absorption characteristic also represents the ability of flour to associate with water under conditions when water is limiting such as dough and pastes.

TSF had higher oil absorption capacity $(1.69 \mathrm{~g} / \mathrm{g})$ than jackfruit seed flour $(0.97 \mathrm{~g} / \mathrm{g})$ and wheat flour $(0.91 \mathrm{~g} / \mathrm{g})$ as reported by Chowdhury et al. (2012) and Akubor et al. (2013), respectively. According to Alzagtat and Alli (2002), the oil absorption capacity depends on the existence of lipid-binding surface of hydrophobic amino acids. Thus, oil absorption capacity of flour is well driven by the presence of protein and high-fat content, which allows more oil to be absorbed. Hydrophobic protein allows binding of lipids occurs. Variations in the polar chain that should not bind on the hydrocarbon chain of the oil to be the cause for the differences oil absorption capacity (Adebowale and Lawal, 2004). The results showed that TSF may be suitable for retaining the taste of food products due to high oil absorption capacity.

The efficiency of emulsification by flour varies with the type, concentration and solubility of the proteins (Elkhalifa and Bernhardt, 2010). Results showed that TSF had $14.8 \%$ of emulsified ability which is higher than wheat flour $(11 \%)$ but lower than akee seed flour (25.65\%) (Akintayo et al., 2002). The emulsified ability of flour varies depending on the type, concentration, and solubility of the proteins (Elkhalifa et al., 2005). Emulsified ability decreases as the changes in coagulation proteins which are hydrophilic and hydrophobic protein allow interaction between the water and oil (Onimawo and Akubor, 2012). Thus, the ability of flour to emulsified also influenced by the fat content in the flour. Highfat content in the TSF caused low protein interactions with other components such as carbohydrate and crude fiber. Negative effect can be seen on the ability of emulsified of high carbohydrate flour, while the high crude fiber than protein in flour also prevents the formation and stabilization of emulsions (Pollard et al., 2002). Therefore, high content of crude fiber and fat than protein content in TSF indicate its unsuitability usage in the production of mayonnaise and sausages.

The least gelation concentration of TSF was $12.00 \%$. The value obtained was higher than results reported for passion fruit kernel flour (10\%) (Akubor et al., 2013), wheat flour (8\%) (Akubor et al., 2013) and jackfruit seed flour (6\%) (Chowdhury et al., 2012). Gelation is an aggregation of denatured molecules. Least gelation concentration varies with different flours in which influenced by the ratio of protein, carbohydrates and fat in the flour (Kaur and Singh, 2005). The imbalances ratio of protein to carbohydrate to fat $(1: 6: 2)$ in the TSF may cause the possible interactions between these components. Results of coagulation denatured molecules also allowed gelatinization occurs, which involves the thermal degradation of starch and associated to the gelatinization ability of globulin ratio in flour (Wani et al., 2012). The least gelling concentration percentage of TSF indicated the flour is not suitable to be used as gelling agent as compared to wheat flour jackfruit seed flour and breadfruit seed flour. Flours with low value of least gelation concentration are reported to be good thickening agents.

Foaming ability of TSF is lower $(7.0 \%)$ than wheat flour $(40 \%)$, passion fruit kernel flour $(20 \%)$ and tapioca flour (13.6\%) (Akubor et al., 2013). Foaming ability of flours was affected by the higher protein content in the flour as the high foaming ability reported for peanut flour (Yu et al., 2007). Good foamability is known to be associated with flexible protein molecules that could reduce surface tension while highly ordered globular protein which is relatively difficult to surface denaturation gives low foamability (Onimawo and Akubor, 2012). According to Yu et al. (2007), besides the structure of the protein that plays an important role in foaming ability, carbohydrate content in the flour also affected. High carbohydrate content has a positive effect on the foaming ability of flour as the hydrophilic component which is enables increasing the viscosity of the solution and at the same time will prevent gas bubbles destroyed (Poole, 1989). Therefore, the ability of TSF to foam may be increased if mixed with other starches such as wheat flour in the production of bakery products.

The swelling ability test used in this study measures the uptake of water by largely undisrupted granules in flour or starch at elevated temperature in the absence of shear forces. It is a measure of hydration capacity because the determination is a weight measure of swollen starch granules and their occluded water. The result for swelling power is presented in Figure 1. The swelling ability of flour samples increased with temperature. At $60^{\circ} \mathrm{C}(1.83$ $\pm 0.32 \mathrm{~g} / \mathrm{g})$ to $70^{\circ} \mathrm{C}(3.91 \pm 0.15 \mathrm{~g} / \mathrm{g})$, the value of swelling ability slowly increased but its ability rapidly increased at $70^{\circ} \mathrm{C}$ to $80^{\circ} \mathrm{C}(8.07 \pm 0.52 \mathrm{~g} / \mathrm{g})$ until 
reached $90^{\circ} \mathrm{C}(26.12 \pm 0.96 \mathrm{~g} / \mathrm{g})$. The swelling power of native flour above $70^{\circ} \mathrm{C}$ increased rapidly due to improvement in hydration of its starch as a result of gelatinization. The results obtained was in agreement with the swelling ability of jackfruit seed flour that swelled well at $85^{\circ} \mathrm{C}$ (Mukprasirt and Sajjaanantakul, 2004) while wheat flour showed lower swelling ability $(7.02-8.72 \mathrm{~g} / \mathrm{g})$ at the temperature of $80^{\circ} \mathrm{C}$ (Appiah et al., 2011). This may due to the presence of the protein component and the amount of starch in the flour (Goesaert et al., 2005). High-amylose starch present in charge of the low swelling ability (Bertuzzi et al., 2007), while the stability of the protein in flour is dependent on the size, charge, hydrophobicity, and flexibility of protein molecules (Turgeon et al., 1992). Thus, the high swelling ability of TSF related to the low amylose content starch and protein stability.

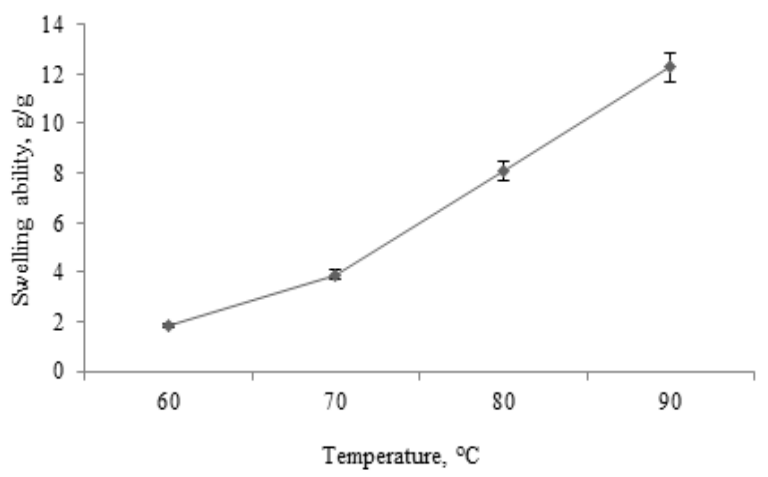

Figure 1 . Swelling ability of TSF at $60,70,80$ and $90^{\circ} \mathrm{C}(\mathrm{n}=3)$.

The RVA pasting properties of TSF is presented in Table 4. Rapid visco-analyzers (RVA) have been extensively used for measuring starch paste viscosity. It is a useful tool for studying starch pasting properties and the effects of food ingredients on starch performance (Ravi et al., 1999). Samples were assessed for pasting temperature, peak time, peak paste viscosity, trough viscosity, breakdown, final and setback viscosity. Pasting temperature and peak time were lower than wheat flour, as reported by Ragaeea and Abdel-Aalb (2006). The values obtained also lower than findings by Mukprasirt and Sajjaanantakul (2004) and Adepeju et al. (2011) of jackfruit and breadfruit seed flour, respectively. This might be due to the higher rate of water absorption (as discussed earlier) that can increase swelling of starch granules.

The highest point during the heating cycle is the peak viscosity. The peak viscosity is considered to represent the equilibrium point between swelling and rupture of starch granules (Newport Scientific, 1995). Peak viscosity of TSF was much higher than jackfruit seed flour (Mukprasirt and Sajjaanantakul, 2004). Lower amylose content was associated with a higher peak viscosity and a lower pasting temperature. Swelling of granules, accompanied by leaching of starch biopolymers, increased the viscosity and during further heating, granules would rupture further which resulted in a decrease in the viscosity.

Table 4. Pasting properties of A. adorotisimmus seed

\begin{tabular}{ll}
\hline \multicolumn{1}{c}{ Parameter } & Tarap seed flour \\
\hline Peak Time (min) & $6.98 \pm 0.54$ \\
Pasting Temperature $\left({ }^{\circ} \mathrm{C}\right)$ & $85.5 \pm 0.03$ \\
Peak Viscosity (RVU) & $1240 \pm 0.21$ \\
Trough Viscosity (RVU) & $1128 \pm 0.14$ \\
Breakdown Viscosity (RVU) & $112 \pm 0.08$ \\
Final Viscosity (RVU) & $1530 \pm 0.11$ \\
Setback Viscosity (RVU) & $402 \pm 0.12$ \\
\hline Results are means \pm standard error $(\mathrm{n}=3)$ &
\end{tabular}

As the starch paste cools, the viscosity increases due to the formation of a gel held together by intermolecular interactions involving amylose and amylopectin molecules. The rate and extent of swelling and breakdown are dependent on the type and amount of starch, the temperature gradient, shear force and composition of the mixture (Debet and Gidley, 2007). TSF showed a lower breakdown viscosity compared to breadfruit seed flour. A lower breakdown suggests that TSF was more resistant to heat and mechanical shear and hence less prone to lost viscosity upon holding and shearing. The final viscosity indicated the re-association of the amylose molecules during the cooling period after gelatinization and a formation of a gel network. TSF exhibited higher final viscosity than jackfruit seed flour but lower than breadfruit seed flour. The setback is defined as the degree of re-association between the starch molecules involving amylose. The setback value recorded for TSF was 402 RVU. Akanbi et al. (2009) reported that the higher the setback value, the lower the retrogradation during cooling and the lower the stale rate of the products made from the starch.

\section{Conflict of interest}

The authors declare that there are no conflicts of interest.

\section{Acknowledgments}

The authors acknowledge the facilities provided and financial supported by the Faculty of Food Science and Nutrition, Universiti Malaysia Sabah (UMS) and Higher Educational Ministry of Malaysia for the study. 


\section{References}

AACC International. (2000). Approved methods of the American Association of Cereal Chemists. $10^{\text {th }}$ ed. St. Paul, MN: AAC International Inc.

Adebowale K.O. and Lawal, O.S. (2003). Functional properties and retrogradation behaviour of native and chemically modified starch of mucuna bean (Mucuna pruriens). Journal Science \& Food Agriculture, 83, 1541-1546.

Adepeju, A.B., Gbadamosi, S.O., Adeniran, A.H. and Omobuwajo, T.O. (2011). Functional and pasting characteristics of breadfruit (Artocarpus altilis) flours. African Journal of Food Science, 5(9), 529-535.

Akanbi, T.O., Nazamid, S. and Adebowale, A. A. (2009). Functional and pasting properties of a tropical breadfruit (Artocarpus altilis) starch from Ile-Ife, Osun State, Nigeria. International Food Research Journal, 16, 151-157.

Akintayo, E. T., Adebayo, E. A. and Arogundade, L. A. (2002). Chemical composition, physicochemical and functional properties of akee (Bilphia sapida) pulp and seed flours. Food Chemistry, 77(3), 333-336.

Akubor, P. I and Ukwuru, M. U. (2003). Functional properties and biscuit making potential of soybean and cassava flour blends. Plant Foods for Human Nutrition, 58, 1-12

Akubor, P.I., Egbekun, M.K. and Obiegbuna, J.E. (2013). Quality assessment of cakes supplemented with cashew pomace and soybean flour. Discovery, 9(20), 8-13.

Akubor, P.I., Isolokwu, P.C., Ugbane, O. and Onimawo, I.A. (2000). Proximate composition and functional properties of African breadfruit kernel and wheat flour blends. Food Research International, 33, 707-712.

Alzagtat, A. A. and Alli, I. (2002). Protein-lipid interactions in food systems: A review. International Journal of Food Sciences and Nutrition, 53(3), 249-260.

AOAC. (2000). Official methods of analysis of AOAC International. (17 $7^{\text {th }}$ ed.) Gaithersburg, MD, USA: AOAC

Appiah, F., Asibuo, J.Y. and Kumah, P. (2011). Physicochemical and functional properties of bean flours of three cowpea (Vigna unguiculata L. Walp) varieties in Ghana. African Journal Food Science, 5(2), 100-104.

Ardabili, G.A., Farhoosh, R. and Haddad, K.M.H. (2011). Chemical composition and physicochemical properties of pumpkin seeds (Cucurbita pepo Subsp. pepo Var. Styriaka) grown in Iran. Journal of Agricultural Science and Technology, 13, 1053-1063.

Arogba, S.S. (1999). The performance of processed mango (Mangifera indica) kernel flour in a model food system. Bioresource Technology, 70(3), 277-281.

Bertuzzi, M. A., Armada, M. and Gottifredi, J. C. (2007). Physicochemical characterization of starch based films. Journal of Food Engineering, 82(1), 17-25.
Butt, M. S. and Batool, R. (2010). Nutritional and functional properties of some promising legumes protein isolates. Pakistan Journal of Nutrition, 9(4), 373-379.

Chowdhury, A.R., Bhattacharyya, A.K. and Chattpadyyay, P. (2012). Study on functional properties of raw and blended jackfruit seed flour (a non conventional source) for food application. Indian Journal of Natural Products and Resources, 3, 347-353.

Debet, M. R. and Gidley, M. J. (2007). Why Do Gelatinized Starch Granules Not Dissolve Completely? Roles for Amylose, Protein, and Lipid in Granule "Ghost" Integrity. Journal of Agriculture and Food Chemistry, 55(12), 4752-4760.

Elkhalifa, A. E. O., Schiffler, B. and Bernhardt, R. (2005). Effect of fermentation on the functional properties of sorghum flour. Food Chemistry, 92(1), 1-5.

Elkhalifa, A.E.O. and Bernhardt, R. (2010). Influence of grain germination on functional properties of sorghum flour. Food Chemistry, 12, 387-392.

Eltayeb, A. R. S. M., Ali, O. A., Abou-Arab, A. A. and Abu-Salem, F. M. (2011). Chemical composition and functional properties of flour and protein isolate extracted from Bambara groundnut (Vigna subterranean). African Journal of Food Science, 5(2), $82-90$.

Fagbemi, T.N. and Oshodi, A.A. (1991). Chemical composition and functional properties of full fat Fluted pumpkin seed flour. Nigeria Food Journal, 9, 26-32.

Galang, F.G. (1955). Fruit and nut growing in the Philippines. Malabon, Rizal, the Philippines: AIA Printing Press.

Goesaert, H., Brijs, K., Veraverbeke, W. S., Courtin, C. M., Gebruers, K. and Delcour, J. A. (2005). Wheat flour constituents: how they impact bread quality, and how to impact their functionality. Trends in Food Science and Technology, 16 (1-3), 12-30.

Hasmadi, M., Madian, A.H. and Sandra, E.H. (2010). Physicochemical properties of commercial semisweet biscuit. Food Chemistry, 121(4), 1029-1038.

Ithnin, B., Mohd Shamsuddin, O. and Mohamed, M.S. (2008). Serangan Perosak Buah-buahan tropika Malaysia. Malaysia: MARDI.

Kaur, M. and Singh, N. (2005). Studies on functional, thermal and pasting properties of flours from different chickpea (Cicer arietinum L.) cultivars. Food Chemistry, 91(3), 403-411.

Landillon, V., Cassan, D., Morel, M. and Cuq, B. (2007). Flowability, cohesive, and granulation properties of wheat powders. Journal of Food Engineering, 86, 178-193.

Li, Y.J. and Yeh, A.I. (2001). Relationships between thermal, rheological characteristics and swelling power for various starches. Journal of Food Engineering, 50, 141-148.

Mbah, B.O., Eme, P.E. and Eze, C.N. (2013). Nutrient potential of Almond seed (Terminalia catappa) sourced from three states of Eastern Nigeria. African Journal of Agricultural Research, 8(7), 629-633. 
Mukprasirt, A. and Sajjaanantakul, K. (2004). Physicochemical properties of flour and starch from jackfruit seeds (Artarpus heterophyllus Lam.) compared with modified starches. International Journal of Food Science and Technology, 39, 271-276.

Newport Scientific (Ed.). (1995). Interpretation. In Operation manual for the series 3. Rapid Visco Analyser. Sydney: Newport Scientific Pty. Ltd.

Onimawo, I.A. and Akubor, P.I. (2012). Food Chemistry: Integrated Approach with Biochemcial background. Nigeria: Joytal Printing Press.

Pollard, N. J., Stoddard, F. L., Popineau, Y., Wrigley, C. W. and MacRitchie, F. (2002). Lupin flours as additives: Dough mixing, breadmaking, emulsifying, and foaming. Cereal Chemistry, 79(5), 662-669.

Poole, S. (1989). Review: The foam-enhancing properties of basic biopolymers. International Journal Food Science Technology, 24, 121-137.

Ragaeea, S. M. and Abdel-Aalb, E.S. (2006). Pasting properties of starch and protein in selected cereals and quality of their food products. Food Chemistry, 95(1), 9-18.

Ravi, R., Sai Manohar, R. and Haridas Rao, P. (1999). Use of rapid visco analyzer (RVA) for measuring the pasting characteristics of wheat flour as influenced by additives. Journal of the Science of Food and Agriculture, 79, 1571-1576.

Rukshan, L. (2001). Special flour for confectionary products. Cereal-bread, 28, 53-58.

Sathe, S.K. and Salunkhe, D.K. (1981). Functional properties of great Northern bean (Phaseolus Vulgaris L.) proteins: emulsion, foaming, viscosity and gelation properties. Journal of Food Science, 46, 71-81.

Sathe, S.K., Deshpande, S.S. and Salunkhe, D.K. (1982). Functional properties of lupin seed (Lupirinus mutabilis) proteins and protein concentrates. Journal Food Science, 47, 491 - 497.

Sharma, A., Jana, A. H. and Chavan, R. S. (2012). Functionality of milk powders and milk-based powders for end use applications-A review. Comprehensive Reviews in Food Science and Food Safety, 11(5), 518528.

Sridaran, A., Karim, A.A. and Bhat, R. (2012). Pithecellobium jiringa legume flour for potential food applications: Studies on their physico-chemical and functional properties. Food Chemistry, 130(3), 528535.

Subhadrabandhu, S. (2001). Under-utilized tropical fruits of Thailand. Under-utilized tropical fruits of Thailand. Bangkok: Kasetsart University.

Tang, Y. P., Linda, B. L. L. and Franz, L. W. 2013. Proximate analysis of Artocarpus odoratissimus (Tarap) in Brunei Darussalam. International Food Research Journal, 20 (1), 409-415.

Turgeon, S.L., Gauthier, S.F., Mollé, D. and Léonil, J. (1992). Interfacial properties of tryptic peptides of B-lactoglobulin. Journal of Agricultural and Food Chemistry, 40, 669-675.
Wani, A. A., Singh, P., Shah, M. A., Schweiggert-Weisz, U., Gul, K. and Wani, I. A. (2012). Rice starch diversity: Effects on structural, morphological, thermal, and physicochemical properties-A review. Comprehensive Reviews in Food Science and Food Safety, 11(5), 417-436.

Yu, J., Ahmedna, M. and Goktepe, I. (2007). Peanut protein concentrate: Production and functional properties as affected by processing. Food Chemistry, 103(1), 121129. 